\title{
PSYCHOLOGICAL WELL BEING PADA MANTAN PENGGUNA NARKOBA DI KOTA PALEMBANG
}

\author{
Muhamad Noor Ikhsan ${ }^{1}$, Desy Arisandy ${ }^{2}$ \\ Fakultas Psiklogi Universitas Bina Darma Palembang \\ Jalan Jendral Ahmad Yani No.12 Palembang \\ Sur-el : 151810039@student.binadarma.ac.id ${ }^{1}$, desy.arisandy@binadarma.ac.id ${ }^{2}$
}

\begin{abstract}
This study aims to determine the psychological well being of former drug users in the city of Palembang. Factors causing well being, and psychological dynamics in former drug users in the city of Palembang, this study uses a qualitative research design and uses a case study approach to be able to find out the causes of well being and psychological dynamics of the research subjects. In this study, researchers used 7 sources, 2 people as research subjects, two people as informants knew from each subject and 2 people as informants. The results of this study found that there are factors that cause both the subject of being well that arises from within oneself (internal) and factors that arise from outside self (external).The two subjects in this study broadly have the same causative factors of being well although there are some differences in the positive emotion and engagement factors found in the study.
\end{abstract}

Keywords: Psychological Well Being, Former Drug User, Case Study Approach

\begin{abstract}
Abstrak : Penelitian ini bertujuan untuk mengetahui psychological well being pada mantan pengguna narkoba di kota palembang. Faktor penyebab well being, dan dinamika psikologis pada mantan pengguna narkoba di kota Palembang, Penelitian ini menggunakan desain penelitian kualitatif serta menggunakan pendekatan studi kasus untuk dapat mengetahui faktor penyebab well being serta dinamika psikologis dari para subjek penelitian. Dalam penelitian ini, peneliti menggunakan 7 orang sumber, 2 orang sebagai subjek penelitian, dua orang sebagai informan tahu dari masing-masing subjek dan 2 orang sebagai informan pelaku. Hasil penelitian ini menemukan bahwa adanya faktor penyebab kedua subjek well being yang muncul dari dalam diri sendiri (internal) dan faktor yang timbul dari luar diri (eksternal). Kedua subjek di dalam penelitian ini secara garis besar memiliki faktor penyebab well being yang hampir sama walaupun terdapat beberapa perbedaan di dalam faktor positive emotion dan engagement yang ditemukan dalam penelitian.
\end{abstract}

Kata Kunci : Psychological Well Being, Mantan Pengguna Narkoba,Pendekatan Study Kasus

\section{PENDAHULUAN}

Permasalahan mengenai obat- obat terlarang atau penyalahgunaan narkoba di negara Indonesia sudah menjadi suatu masalah yang amat serius. Seseorang yang pada awal mulanya awam terhadap obatobatan atau narkoba berubah menjadi seorang pecandu obat-obatan terlarang atau narkoba 
yang akan sulit terlepas dari ketergantungannya. Kemudian program tentang rehabilitasi narkoba merupakan salah satu persiapan untuk kembali ke lingkungan masyarakat (reentry program). Kemudian dari sudut pandang psikososial bahwa sanya, seorang individu yang menyalahgunakan obat-obatan atau narkoba terjadi dari akibat negatif dari interaksi dengan sosial yang tidak kondusif (tidak mendukung ke arah positif). Dampak dari penyalahgunaan narkotika ini adalah suatu dampak memburuknya hubungan keluarga, kemudian akan terjadi pengasingan dari masyarakat dan akan dianggap tidak dapat tampil maksimal di lingkungan masyarakat.

Berdasarkan data yang peneliti dapatan dari Sindonews.com Badan Narkotika Nasional (BNN) menyebutkan pada tahun 2018

Provinsi Sumsel dalam darurat narkoba, sebanyak 102.000 warga dari

8,2 juta jiwa, penduduk Sumsel merupakan pecandu narkoba dari prevalensi nasional $1,77 \%$ dan sudah barang tentu hal ini sangat menghawatirkan mengingat sebanyak 30.055 penggguna merupakan siswa yang masih duduk dibangku SMA, kemudian solusi bagi para penyalah guna narkoba tidak lain adalah rehabilitasi.

Program dari rehabilitasi narkoba inilah yang menjadi salah satu langkah yang akan di ambil, serius dan tepat di dalam penanganan pada penyalahgunaan narkoba. Dalam undang-undang Republik Indonesia Nomor 35 tahun 2009 pasal 54 tentang narkotika jelas dikatakan bahwa pecandu narkotika dan korban dari penyalahgunaan narkotika wajib menjalani suatu proses rehabilitasi medis \& rehabilitasi kearah sosial, kemudian bagi para korban penyalahgunaan narkoba mereka sangat membutuhkan bantuan agar mereka dapat melangsungkan kembali kehidupannya sesuai dengan fungsi sosialnya melalui proses rehabilitasi narkoba, dan kemudian hal ini lah yang membuat peneliti tertarik untuk melakukan penelitian kepada mantan pengguna narkoba yang telah berhenti mengunakan narkoba, baik pengguna yang berhenti melalui proses rehabilitasi maupun yang tidak melalui proses rehabilitasi untuk melihat perubahan positif atau psychological well being yang terjadi pada diri mantan pengguna narkoba.

Sarwono (2015) bahwa pelarian remaja lebih kearah narkoba dan alkohol yang sifatnya menimbulkan ketergantungan (kecanduan) pada pemakainya yang mana narkoba menurut pakar kesehatan, narkoba sebenarnya adalah senyawa - senyawa psikotropika yang biasa dipakai untuk membius pasien yang hendak dioperasi atau digunakan untuk penyakit - penyakit tertentu.

Mardani (2008) menyatakan bahwa individu yang paling banyak ditemui dalam 
kasus penyalahgunaan narkoba adalah remaja, dengan rentang usia 19-22 tahun yang tergolong dalam remaja akhir. kaum Remaja menjadi salah satu kelompok yang rentan terhadap penyalahgunaan narkoba, karena selain memiliki suatu sifat yang dinamis, energik, akan selalu ingin tahu. Mereka juga akan sangat mudah untuk merasa putus asa dan akan mudah untuk dipengaruhi oleh teman sepergulan hingga para bandar atau pengedar narkoba yang akan berakibat pada terjerumus ke suatu masalah tentang penyalahgunaan narkoba.

Berdasarkan uraian di atas dapat di simpulkan bahwa penyebab dari seseorang menjadi penyalahguna narkoba adalah karena adanya keinginan untuk coba - coba, penggunaan rutin, akan berakibat pada adanya suatu kebutuhan untuk meningkatkan dosis dari pemakaian agar mendapatkan suatu efek yang diinginkan penggunanya, kemudian akan terjadi ketergantungan lalu akan terjadi gejala putus zat apabila tidak mengkonsumsi zat, dan terus berlanjutnya penggunaan zat walaupun adanya masalah yang muncul akibat penggunaan zat.

\section{Aspinwal (2002) kesejahteraan}

psikologis adalah gambarab dari bagaimana fungsi dari psikologis berjalan dengan baik \& positif. \& sama halnya juga apa yang di katakan oleh Schultz (Tia Ramadhani, 2016) mendefinisikan dari kesejahteraan psikologis (psychological wellbeing) yang mana sebagai fungsi yang positif dari individu, dimana fungsi yang positif dari individu adalah arah atau suatu tujuan yang harus diusahakan untuk dicapai oleh individu yg sehat.

Psychological well being merupakan suatu kondisi psikologis individu yang sehat yang akan ditandai dengan berfungsinya aspek-aspek dari psikologis yg positif di dalam prosesnya menuju aktualisasi diri. Ryff (1989) mengatakan bahwa ada enam aspekaspek dari kesejahteraan psikologis antara lain yaitu, aspek penerimaan diri, aspek hubungan

positif dengan orang lain, aspek kemandirian, aspek penguasaan lingkungan, aspek tujuan hidup dan aspek pengembangan pribadi.

Maka dari itu peneliti tertarik untuk menggunakan variabel psychological well being yang mana menurut teori yang terdapat pada psychological well being seorang individu yang memiliki kesejahteraan psikologis (psychological well being) yang baik akan mampu menjalankan dan mencapai tugas perkembangannya dengan baik. sebaliknya individu yang memiliki psychological well being yang kurang baik akan sulit bahkan gagal untuk mencapai tahap perkembangannya. kehadiran psychological well-being dalam diri seseorang membuat ia mampu untuk menjalankan fungsi psikologisnya dengan lebih baik, termasuk dalam hal belajar dan pencapaian prestasi 
Chow (2007).

\section{METODOLOGI PENELITIAN}

Teknik yang digunakan dalam penelitian ini adalah gabungan dari tehnik observasi, wawancara dan dokumentasi. Penjelasan dari tehnik- tehnik yang digunakan didalam penelitian ini yaitu :

\section{Observasi}

Observasi atau pengamatan, meliputi kegiataan pemuatan perhatian tehadap suatu obyek dengan menggunakan seluruh alat indra(Arikunto, 2006). Menurut Patton ( Sugiyono,2012) manfaat observasi adalah sebagai berikut :

a. Melalui observasi dilapangan akan lebih mampu memahami konteks data dalam keseluruhan situasi sosial, jadi akan dapat diperoleh pandangan yang holistik atau menyeluruh.

b. Melalui observasi maka akan diperoleh pengalaman langsung, sehingga memungkinkan peneliti menggunakan pendekatan induktif, jadi tidak dipengaruhi oleh konsep atau pandangan sebelumnya

c. Melalui observasi peneliti dapat melihat hal hal yang kurang atau tidak diamati oleh orang lain, khususnya orang yang berada dalam lingkungan itu, karena telah dianggap biasa" dan karena itu tidak akan terungkapkan dalam wawancara d. Melalui observasi, peneliti dapat menemukan hal hal yang sedianya tidak terungkapkan oleh responden dalam wawancara karena bersifat sensitif atau ingin ditutupi karena dapat merugikan nama lembaga.

e. Melalui observasi, peneliti dapat menemukan hal hal diluar persepsi responden, sehingga peneliti memperoleh gambaran yang lebih kompresif.

f. Melaui pengamatan dilapangan, peneliti tidak hanya mengumpulkan data yang kaya, tetapi juga memperoleh kesan kesan pribadi dan merasakan suasana situasi sosial yang diteliti

Tehnik observasi yang dilakukan oleh peneliti adalah tehnik observasi partisipan pasif (passive partisipattion). Jadi dalam hal ini peneliti peneliti datang ketempat kegiatan orang yang diamati, tetapi tidak ikut terlibat dalam kegiatan tersebut(Sugiyono, 2012). Namun jika situasi dan kondisi memungkinkan, peneliti juga akan melakukan observasi parisipatif aktif atau bahkan observasi terus terang atau tersamar. Observasi partisipatif aktif menurut Sugiyono (2012) adalah peneliti ikut melakukan apa yang dilakukan oleh sumber data, tetapi belum sepenuhnya lengkap. Tehnik obsevasi ini peneliti akan mengamati pola kehidupan mantan pengguna narkoba. Dimulai dari subjek penelitian, aktifitasnya, 
bentuk emosi dan interaksi subjek dengan orang lain ketika berada dilingkungan sosialnya

\section{HASIL DAN PEMBAHASAN}

Penelitian ini dilakukan di kota Palembang, tentang mantan penyalahgunaan narkoba yang berhenti menggunakan narkoba. Kota palembang merupakan kota yang sangat pesat perkembangannya terutama dalam hal infrastruktus. Dalam penelitian ini, peneliti mengggunakan 6 orang sumber, 2 orang sebagai subjek penelitian, 4 orang sebagai informan tahu dari masingmasing subjek penelitian (keluarga dari subjek penelitian), serta dua orang sebagai informan pelaku.

Subjek pertama yang berinisial $\mathrm{T}$ memiliki latar belakang keluarga dari kelas ekonomi menengah atas ayah $\mathrm{T}$ seorang wiraswasta yang memiliki pendapatan yang mencukupi seluruh kebutuhan keluarga sedangkan ibunya merupakan seorang ibu rumahtangga,subjek pertama adalah seorang pria berusia 25 tahun dengan tinggi $178 \mathrm{~cm}$ berat badan $80 \mathrm{~kg}$ dan berkuit hitam., subjek merupakan anak ke 3 dari 5 orang bersaudara,subjek T pertama kali menggunakan narkoba pada saat masih duduk dibangku SMA yang mana penggunaan narkoba tersebut disebabkan oleh pergaulan yang salah yang kemudian $\mathrm{T}$ berhenti menggunakan narkoba tanpa melalui proses rehabilitasi.
Subjek kedua berinisial DA, subjek memiliki latar belakang keluarga dari kelas ekonomi menengah keatas ayah DA merupakan seorang pegawai negeri sipil/ PNS kemudian ibu DA juga bekerja sebagai pegawai negeri sipil/ PNS, subjek merupakan anak pertama dari lima orang bersaudara, subjek kedua adalah seorang pria berusia 27 tahun dengan tinggi $175 \mathrm{~cm}$ berat badan $70 \mathrm{~kg}$ dan berkulit sawo matang, berdasarkan pengaakuan subjek pertama kali menggunakan narkoba pada saat subjek masih duduk dibangku SMP dan penggunaan narkoba tersebut diakui oleh subjek DA tanpa adanya faktor pengaruh dari teman, subjek menggunakan narkoba murni karena keinginannya sendiri.

Sumber data ketiga adalah informan pelaku dari subjek pertama $\mathrm{T}$ yang berinisial A yang berusia 25 tahun dengan ciri-ciri fisik memiliki tinggi tubuh sekitar $176 \mathrm{~cm}$ dan berat badan $75 \mathrm{~kg}$, serta memiliki warna kulit sawo matang. A juga merupakan mantan pengguna narkoba dan merupakan salah satu teman dekat dari subjek $T$, dan saat ini A bekerja disalah satu perusahaan swasta.

Sumber data keempat adalah informan tahu dari subjek $\mathrm{T}$ yang merupakan kakak kandung dari subjek T. Informan tahu ini berinisal "PNT" memiliki ciri-ciri fisik gemuk dengan tinggi badan sekitar 170, dengan kulit yang berwarna sawo matan. 
PNT bekerja disalah satu perusahaan swasta di kota Palembang.

Sumber data kelima adalah informan tahu dari subjek DA yang merupakan adik sepupu dari subjek DA yang tinggal daerah OPI tepatnya di Jl. Sumatera II. Saudara sepupu DA ini berinisial "WK" memiliki ciri-ciri fisik yaitu rambut yang berwarna hitam, dengan kulit yang berwarna sawo matang, serta badan tinggi sekitar $168 \mathrm{~cm}$ dan dengan berat sekitar $50 \mathrm{~kg}$. WK saat ini sedang menempuh pendidikan disalah satu universitas yang ada di kota Palembang

Sumber data keenam adalah informan tahu dari subjek DA yang merupakanteman dekat atau pacar dari subjek DA. Informan tahu ini berinisal " $\mathrm{A}$ " memiliki ciri-ciri fisik yaitu rambut yang berwarna hitam sepunggung, dengan kulit yang berwarna putih, serta badan dengan tinggi $165 \mathrm{~cm}$ dan berat badan proposional. A saat ini bekerja disalah satu perusahaan yang bergerak dibidang pemasaran rumah.

Berdasarkan hasil analisis yang dilakukan peneliti dapat ditarik kesimpulan bahwa adanya persamaan secara garis besar mengenai dinamika psikologis yang dimiliki oleh kedua subjek mengenai psychological well being yang mereka tunjukkan. Kedua subjek dalam penelitian ini adalah $\mathrm{T}$ dan DA mereka menunjukan bentuk- bentuk dari well being, mulai dari penerimaan diri, hubungan yang positif dengan lingkungan, otonomi, penguasaan lingkungan, pertumbuhan pribadi, positive emotion, engagement, relationship, meaning of life, accomplishmen, religiusitas, serta dukungan sosial.

Faktor penyebab well being pada kedua subjek penelitian ini cenderung sama walaupun terdapat perbedaan pada beberapa faktor seperti positive emotion dan engagement yang mana subjek pertama $\mathrm{T}$ memiliki faktor positive emotion dan engagement yang dapat di katakan jauh lebih baik ketimbang subjek kedua DA.

Faktor positive emotion pada subjek T lebih baik karena di dalam proses wawancara dan observasi yang telah peneliti lakukan di temukan adanya hal-hal yang dapat dikatakan memenuhi syarat dari positive emotion seperti adanya empathy, trust, love, forgiveness yang baik, sebagai contoh subjek $\mathrm{T}$ mengatakan bahwa dirinya dapat ikut merasakan suatu kesulitan yang sedang dirasakan oleh seorang teman atau anggita keluarganya, kemudian di dalam hal memeberikan maaf subjek $\mathrm{T}$ mengtakan bahwa dirinya sangat mampu untuk memberikan maaf kepada seseorang yang telah melakukan kesalahan kepadanya dan $\mathrm{T}$ lebih memilih untuk tidak menyimpan rasa dendam, di tambah lagi subjek $\mathrm{T}$ merasakan suatu kebahagiaan dan kepuasan di saat dapat memberikan suatu pertolongan atau bantuan kepada seseorang yang berada 
di sekelilingnya seperti keluarga, teman, dan klien di mana tempat subjek $\mathrm{T}$ bekerja, kemudian di dalam faktor engagement subjek $\mathrm{T}$ memiliki keyakinan-keyakinan akan kemampuan pada diri sendiri untukbisa meraih setiap apa yang dirinya inginkan dan subjek $\mathrm{T}$ menambahkan bahwa apa yang saat ini dirinya lakukan adalah salah satu bentuk atau salah satu faktor-faktor pendukung dalam perjalanannya mencapai semua tujuan yang subjek T inginkan .

Namun berbeda dengan subjek DA di dalam hal positive emotion dapat di katakan tidak memenuhi syarat dari empathy, trust, love, forgiveness yang baik karena di dalam wawancara yang telah peneliti lakukan subjek DA mengatakan bahwa dirinya tidak merasakan kebahagiaan atau kepuasan atas suatu bantuan yang telah dirinya berikan kepada seseorang karena dirinya merasa hal tersebut tidak akan memberikan keuntungan kepada dirinya, subjek DA juga mengatakan bahwa dirinya sangat sulit di dalam hal mempercayai orang lain dan di tambah pernyataan dari subjek DA yang menyatakan bahwa dirinya tidak akan dapat memberikan maaf kepada seseorang yang telah melakukan suatu kesalahan kepada dirinya, kemudian dalam faktor engagement subjek DA mengatakan tidak memiliki suatu keyakinan atau kemampuan di dalam dirinya untuk bisa mewujudkan semua impian atau cita-cita yang dirinya inginkan, dan DA menambahkan bahwa apa yang saat ini dirinya lakukan tidak akan dapat mendukung dirinya di dalam mecapai semua tujuan yang di inginkan, maka dari hal-hal di atas ini lah yang meyakinkan peneliti bahwa well being pada subjek T lebih baik ketimbang subjek DA.

Di dalam proses wawancara dan observasi di temuan beberapa temuan di luar dari tema penelitian pada subjek $\mathrm{T}$ yaitu adanya hardiness, hardiness adalah pola sikap dan strategi yang membentuk suatu keberanian dan motivasi yang ada untuk melakukan kerja keras untuk mengubah keadaan yang penuh tekanan dari bencana potensial menjadi peluang pertumbuhan, hardiness yang terlihat pada $\mathrm{T}$ adalah adanya motivasi dan kerja keras, subjek $\mathrm{T}$ selain bekerja di salah satu panti rehabilitasi rehabilitasi narkoba yang mana sebenarnya dirinya sudah memiliki penghasilan tetap, namun dirinya lebih memilih untuk mengerjakan suatu usaha sampingan seperti perkerjaan yang bersifat perbaikan pada alatalat elektronik, hal ini $\mathrm{T}$ lakukan demi memaksimalkan waktu luang yang di milikinya untuk bisa menjadi suatu kegiatan positif yang tentunya juga menghasilkan.

Sedangkan temuan yang peneliti dapatkan dari subjek kedua DA yaitu subjek DA menunjukan bahwa adanya kecendrungan akan kecanduan pada game online, hal ini 
peneliti temukan di beberapa bulan terakhir yaitu sekitar bulan mei 2019 sampai dengan saat ini, dari kecendrungan akan kecanduan game online ini lah yang menyebabkan beberapa faktor dari well being subjek DA menjadi buruk yaitu faktor positive emotion dan engagement, kemudian beberapa perilaku negatif yang DA tunjukan saat dirinya sedang atau pun sesudah dirinya bermain game online diantaranya seperti DA sulit untuk mengontrol emosi, sulit untuk di ajak berkomunikasi di saat dirinya sedang bermain game, lebih memilih menghabiskan waktu dengan bermain game online dari pada melakukan hal- hal yang lebih bermanfaat, dan hal-hal tersebut dapat terjadi karena pengaruh negatif dari game online.

\section{SIMPULAN}

Berdasarkan dari penelitian dapat disimpulkan bahwa hampir secara keseluruhan baik subjek $\mathrm{T}$ dan subjek DA memiliki kesamaan dalam hal-hal yang berhubungan dengan faktor-faktor well being. Namun terdapat beberapa perbedaan pada faktor positive emotion dan engagement yang mana subjek pertama $\mathrm{T}$ memiliki faktor positive emotion dan engagement yang dapat di katakan jauh lebih baik ketimbang subjek kedua DA. Di tambah dengan temuan di luar dari tema penelitian yang mana terdapat hardiness pada diri subjek $\mathrm{T}$, kemudian temuan di luar dari tema penelitian yang di dapatkan pada subjek kedua DA yang mana DA menunjukan adanya kecendrungan akan kecanduan pada game online. 


\section{DAFTAR RUJUKAN}

Aspinwall, L. G., Richter, L., \& Hoffman, R. R. (2002). Understanding how optimism works: An examination ofoptimists' adaptive moderation belief and behavior. Washington: American Psychological Association. A

Agi S.N (2016), Hubungan Antara Dukungan Sosial Dengan Psychological WellBeing Pada Guru Honorer Daerah. Naskah Publikasi Universitas Muhammadiyah Surakarta (UMS).

Azizah Batubara. (2007) Hubungan Antara Religiusitas dengan Psychological well being ditinjau dari Big Five Personality Pada siswa SMA negeri 6 Binjai.

Ahmadi, R. (2014). Metodologi Penelitian Kualitatif. Yogyakarta. Ar-Ruzz Media.

Chow, V. T., Maidment, D. R. \& Mays, L. W., Applied Hydrology. New York, U.S.A: McGraw-Hill. Indah fitri Shobihah (2007)

Chow, V. T, Chan, Y. C, Yong, R. et al, (1998). Monitoring of Dengue Viruses in Field Cought Aedes Aegypti and Aedes Albopictus by A Type-Specific PCR and Cycle Squencing, Indah fitri Shobihah (2007)

Hawari, D. (2003). Penyalahgunaan dan Ketergantungan Napza (Narkotika, Alkohol Dan Zat Adiktif). Fakultas Kedokteran Universitas Indonesia (FK.UI). Jakarta.

Hurlock, E.B. (1980). Psikologi Perkembangan: Suatu Pendekatan Sepanjang Rentang Kehidupan. Erlangga. Jakarta.

Herdiansyah, H. (2012) Metodologi Penelitian Kualitatif : Untuk Ilmu Ilmu
Sosial. Salemba Humanika : Jakarta.

Heizomi (2015) Happiness And Its Relations To Psychological Well Being Of Adolascents

Mardani. 2008. Penyalahgunaan Narkoba dalam Perspektif Hukum Islamdan

Hukum Pidana Nasional. Jakarta: Raja Grafindo Persada.

Mario Valentino Tandjing (2015) Hubungan Antara Kesejahteraan Psikologis Pada Mahasiswa Fakultas Psikologi UKSW Tingkat Akhir

Mega Tala Harimukthi M.T (2014) Eksplorasi Kesejahteraan Psikologis Individu Dewasa Awal Penyandang Tunanetra

Meidian Citaring Nastiti (2014) Psychological well being Pada Guru Yang Telah Menjalani Masa Pensiun Nevid, J.S. dkk. (2005) Psikologi Abnormal Edisi Kelima, Erlangga : Jakarta.

Nevid, J.S, dkk. 2005. Psikologi Abnormal edisi kelimaJilid 1. Jakarta:Erlangga.

Nevid, J.S. dkk. (2005) Psikologi Abnormal Edisi Kelima, Erlangga : Jakarta.

Rahmawati Brilianita Sari (2015) Tingkat Psychological well Being pada remaja Di panti Sosial Bina Remaja Yogyakarta

Psychological Well-Being Perempuan Bekerja dengan StatusMenikah dan Belum Menikah (SKRIPSI). Ferny Santje Lakoy .(2009).

Poerwandari, E. K. (2001). Pendekatan Kualitatif Untuk Penelitian Perilaku Manusia. Lembaga Pengembangan Sarana Pengukuran dan Pendidikan Psikologi (LPSP3) Fakultas Psikologi Universitas Indonesia. 
Ryff, C.D. (1989). Happiness is Everything, or is it? Exploration on The Meaning of Psychological Well-Being Journal of Personality and Social

Psychological,57, 1060-1081.

Ryff, C.D. (1989). Beyond Ponce Deleon and Life Satisfaction: New Directions In Quest of Successful Ageing. Interactional Journal of Behavioral Development, 12 (1) 35-55.

Ryff, C. D. \& Essex, M. J. (1992). The Interpretation of Life Experience and WellBeing : The Sample Case of Relocations Psychological and Aging, 7 : 507- 517.

Ryff, C. D. (1995). Psychological WellBeing in Adult Life. Current Directions In Psychological Science, vol 4:99-104

Ryff, C. D., Singer, B. (1996). Psychological Well-Being: Meaning, Measurement, and Implication for Psychotherapy Research. Psychotherapy

Santrock, J. (2002). Life-Spam Development : Perkembangan Masa Hidup. Edisi Ke -6. Erlangga. Jakarta.

Santrock, J. (2007). Adolescence : Perkembangan Remaja. Edisi $\mathrm{Ke}-6$. Erlangga.

Susanti (2012) Hubungan Antara Psychological well being Pada Wanita Lajang Ditijau Dari Bidang Pekerjaan 